The Opposite of Backlash:

High-SDO People Show Enhanced Tolerance When Gay People Pose Little Threat

\author{
Angela J. Bahns \\ Wellesley College
}

Christian S. Crandall

University of Kansas

This is the final accepted version of the following article:

Bahns, A. J., \& Crandall, C. S. (2013). The opposite of backlash: High-SDO people show enhanced tolerance when gay people pose little threat. European Journal of Social Psychology Special Issue: Psychological Perspectives on the Legitimation of Social Inequality, 43, 286-291, doi: 10.1002/ejsp.1947, which has been published in final form at http://onlinelibrary.wiley.com/doi/10.1002/ejsp.1947/abstract

Running Head: OPPOSITE OF BACKLASH

Correspondence concerning this article should be addressed to:

Angela Bahns

Department of Psychology

Wellesley College

106 Central Street

Wellesley, MA, 02481

Email: abahns@wellesley.edu

Tel: 781-283-3560

Fax: 781-283-3730 


\begin{abstract}
We tested how perceived threat to group position affects the relationship between beliefs about the acceptability of social inequality — as measured by social dominance orientation (SDO) - and discrimination. We hypothesized that high-SDO heterosexuals would respond with increased discrimination when they perceived status gains for gays. In a pilot study, we found that SDO correlated with gay prejudice and with perceiving gays to be gaining status. In an experiment, we manipulated the perceived status of gays and measured SDO, traditional values and money donated to anti-gay causes. SDO was correlated with more anti-gay donations, except when gays were perceived to be low in status; then people high in SDO discriminated less, making fewer anti-gay donations in the Low compared to the Gain and Control status conditions. By contrast, traditional values were correlated with more anti-gay donations in all conditions, and the correlation was especially strong in the Low status condition.
\end{abstract}

Key words: social dominance orientation, anti-gay discrimination, legitimacy, perceived group status 


\section{The Opposite of Backlash:}

\section{High-SDO People Show Enhanced Tolerance When Gay people Pose Little Threat}

We consider how beliefs about social inequality may be used to legitimize anti-gay

discrimination when relative status positions between heterosexuals and gay people ${ }^{1}$ are in flux. Ideologies that legitimize the prevailing status hierarchy, in which heterosexuals are relatively advantaged and gay people are relatively disadvantaged (Carpenter, 2008), allow prejudice and discrimination against gay people to persist. We propose that heterosexuals who endorse social inequality are more likely to discriminate against gay people when they perceive that gay people are gaining rights and influence, in part because status gains for low status groups threaten to disrupt the very system of social inequality they view as fair and just (Jost \& Major, 2001).

Social dominance theory (SDT; Sidanius \& Pratto, 1999) asserts that group-based status hierarchies are maintained by high status group members acting to defend their group's position. One effective way to do this is to discriminate against outgroup members, in order to affirm the legitimacy of the ingroup's dominant position (Branscombe, Ellemers, Spears, \& Doosje, 1999). If low status groups' status gains are perceived to pose a threat to the group position of high status groups (Blumer, 1958; Bobo, 1999), prejudice and discrimination may be seen as legitimate responses. According to SDT, discrimination against gay people by heterosexuals in large part occurs because of group differences in power (Sidanius, Pratto, Van Laar, \& Levin, 2004); heterosexuals are more able to impose their will on gay people without resistance than are gay people able to impose their will on heterosexuals.

One of the basic assumptions of SDT is that social dominance orientation (SDO; Pratto, Sidanius, Stallworth, \& Malle, 1994) — the extent an individual endorses group-based inequality—is a marker of sensitivity to status differences between groups. If people high in 
SDO endorse social inequality, then they should be especially responsive to information about relative group status. SDO is also sensitive to context. When a particular group-based distinction is primed, SDO should be associated with greater support for discriminatory policies and increased prejudice toward the salient outgroup, as a way to legitimize the existing status gap (Pratto, Sidanius, \& Levin, 2006; Pratto, Stallworth, \& Conway-Lanz, 1998). Thus when heterosexuals are reminded of their dominant group position relative to gay people, SDO should be correlated with increases in prejudice and discrimination against gay people and with opposition to gay rights. Previous research has borne this out (e.g., Whitley \& Ægisdottir, 2000).

The primary goal of this research is to determine whether the relationship between SDO and anti-gay discrimination is moderated by perceived threat to group position. Sidanius and colleagues (2000) proposed that SDO interacts with perceived social threats, and Pratto \& Shih (2000) found that SDO was unrelated to implicit prejudice except when the elite status and prestige of the ingroup was under threat. Thus we propose that heterosexuals who endorse social inequality (i.e., those who are high in SDO) may only discriminate against gay people when the legitimacy of their group's dominant position is called into question, such as when gay people are making status gains.

To the extent that social status is not strictly competitive, advances for low status groups need not mean loss of status for high status groups. But high-SDO individuals believe in the legitimacy of social inequality, and this can lead to zero-sum thinking about status (Eibach \& Keegan, 2006; Esses, Jackson, \& Armstrong, 1998). Perceived threat to group position can certainly serve as justification for prejudice and discrimination (Crandall \& Eshleman, 2003; Periera, Vala, \& Costa-Lopes, 2010). Granting rights to gay people does not take away rights from heterosexuals (cf. Sokolowski, 2004), but heterosexuals—especially those high in SDO- 
might be motivated to view the status gains as threatening, because threat perception is a means of legitimizing their opposition to gay rights. We predict that heterosexuals who are high in SDO will discriminate against gay people more than will heterosexuals who are low in SDO, especially when they perceive gay people to be gaining status.

By contrast, traditional values reflect deeply held personal beliefs about specific social issues such as abortion or gay rights, and are less involved with relative social position. Traditional values are expected to be associated with increased discrimination (Adorno, FrenkelBrunswik, Levinson \& Sanford, 1950; Crandall, 1994; Pettigrew \& Meertens, 1995), but this relationship should be unaffected by perceived relative group status.

\section{Pilot Study}

SDO is associated with prejudice toward gay people and with opposition to gay rights (Whitley, 1999), but what is its relation to the perceived relative group status of heterosexuals and gay people? We first ran a pilot study to test the hypothesis that high-SDO heterosexuals perceive gay people to be gaining status, in the absence of explicit information regarding gay people's status. Because of their commitment to defending their own status position, high-SDO people may chronically perceive that gay people pose a threat to heterosexuals' group position. High status groups perceive more progress toward equality than low status groups, particularly for high-SDO individuals and when progress is framed as high status group loss rather than as low status group gain (Eibach \& Keegan, 2006). We propose that commitment to social inequality (SDO) may also be associated with the perceived status of gay people.

As part of an in-class exercise, we had 41University of Kansas undergraduates (24 men, 17 women, 18-25 years old) fill out a questionnaire. All but two participants were U.S. citizens, and all participants identified themselves as heterosexual. 
The questionnaire included the 14-item SDO scale (Pratto et al., 1994; $\alpha=.81$ ), the 20item Attitudes Toward Lesbians and Gays scale (ATLG; Herek, 1994; $\alpha \mathrm{s}=.82$ and .80 for the ATL and ATG subscales, respectively), and the 7-item Perceived Status of Gay People scale $(\alpha=.82)$, adapted from the Right-Wing Authoritarianism scale (Altemeyer, 1981). Example items from the Perceived Status of Gay People scale are "Gays are gaining power and influence in our society," and "Liberals and gay rights advocates are taking over this country." All scales were from 1 (very negative) to 7 (very positive); higher scores indicate endorsement of social inequality, positive attitudes, and the perception that gay people are gaining status.

As predicted, higher levels of SDO were associated with a higher perceived status of gay people (see Table 1). SDO was also negatively correlated with ATL and ATG scores, indicating that SDO is associated with more negative attitudes toward lesbians and gay men, respectively; people high in SDO were more likely to be prejudiced and more likely to perceive that gay people are gaining rights and influence.

Among members of high status groups, SDO is usually associated with greater perceived progress toward social equality (i.e., smaller perceived status gaps; Eibach \& Keegan, 2006). Table 1 is consistent with this pattern - high SDO is associated with the perception that gay people are increasing in status. A higher preference for status distinctions among heterosexuals was associated with a sense that gay people are gaining on them and with increased prejudice.

\section{Experiment 1}

With evidence of a connection between SDO, prejudice, and status threat in hand, we experimentally manipulated status threat by presenting direct information about gay people's status. To the extent that status relations are viewed in zero-sum terms, heterosexuals are threatened by advances in gay rights. We measured anti-gay discrimination in terms of donations 
made to organizations with hierarchy-enhancing ideologies compared to organizations with hierarchy-attenuating ideologies (Sidanius \& Pratto, 1999). "Pro-gay" organizations like the Human Rights Coalition ${ }^{2}$ are hierarchy attenuating because they allocate resources in ways that extend rights and benefits to gay people; "anti-gay" organizations like the Traditional Values Association and Family First are hierarchy enhancing because they allocate resources in ways that reinforce heterosexuals' dominant group position.

Participants were given coins to donate to beneficiaries that support, oppose, or were unrelated to gay rights. We predicted that high-SDO people would donate more money to antigay causes, especially when gay people were perceived to be gaining status. Individuals who are high in SDO endorse a system of social inequality; when low status groups start moving up, the distinction between high and low status groups is blurred. Consequently, we expected that highSDO heterosexuals would donate more money to anti-gay causes when gay people are gaining status as a way to "push them back down" and also that they might show enhanced tolerance, donating less money to anti-gay causes (and more money to pro-gay causes) when gay people pose little threat to group position.

By contrast, individuals who hold traditional values are opposed to the advancement of gay rights because of deeply held personal beliefs; they should be insensitive to relative group status. We predict that people with traditional values should donate more money to anti-gay causes than people with less traditional values regardless of information about gay people's status.

\section{Method}

Participants. Participants were 74 heterosexual undergraduates (50 women and 24 men, 18-37 years old) at the University of Kansas who received course credit for participation. 
Materials and Procedure. Participants were told that the researchers were interested in altruistic behavior and that as participants they would make real donations to nonprofit organizations. Participants first read the mission statements of the six beneficiaries (see Table 2), in order to decide to which organizations they wished to donate. Next participants read additional materials from two of the organizations. Participants drew a slip of paper which ostensibly determined which organizations' materials they would read, however in actuality all participants read about the same two organizations and drawing the slip of paper randomly assigned participants to status condition. To minimize demand, all participants first read information from the Cancer Awareness Society, and then read information from the Human Rights Coalition that varied by status condition. Having participants read materials from only two of the organizations helped to avoid fatigue and to avoid any unintended effects that materials from the anti-gay organizations might have had on the manipulation of status. Then participants completed the measures of SDO and traditional values. ${ }^{3}$

Lastly, participants made their donations in private. They were given a container of coins and instructed to donate all of the money. Each container included fifteen dimes and fifteen pennies. Participants were told, "While the amount of money you are donating individually is small, we will be running many participants in this study, so the joint impact will be large." All coins in a container shared the same mint date, which allowed us to track the donations without removing coins after each participant. Each session started with an equal amount of coins in each jar which all shared the same mint date and were not included in the calculation of donations. After making their donations, participants were debriefed.

Status Manipulation. In the Gain status condition, participants read an article that emphasized the progress toward equality that is being made in the areas of religion, politics, job 
benefits, marriage rights, media representation, and education, noting, "Lesbian, gay, bisexual, and transgender (LGBT) individuals are making huge advances in gaining political leverage and are quickly becoming successful and respected members of American society.”

In the Low status condition, the article emphasized the current low status of LGBT individuals and their difficulty in achieving equality in the same areas, noting, "LGBT individuals have very limited political leverage and are experiencing considerable difficulty in becoming successful and respected members of American society."

In the Control condition, the article was unrelated to group status. The article contained information about public services and community events sponsored by the HRC, noting that the HRC's mission is “establishing a network of communication which allows LGBT individuals to stay connected to one another and provides a forum for discussing community affairs."

A single item manipulation check was at the end of the HRC article. "I would say from reading the report that gay people in our society are: (a) widely discriminated against with little legal protection, (b) interested in health care and social security, (c) making huge advances in gaining rights and influence.” These data were collected well before the 2012 U.S. election, in which marriage equality received substantial support in several regions of the country.

Individual difference measures. SDO was measured using the 14-item version of Pratto et al.'s (1994) scale $(\alpha=.86)$.

Traditional values were measured with 7 items $(\alpha=.77)$. Four items came from Fischer's (1982) traditionalism scale which measures traditional attitudes in regard to social issues, such as "Do you think the use of marijuana should be made legal?" (1=Yes, $4=$ It depends, $7=\mathrm{No})$. We added three additional items using the scale 1 (strongly disagree) to 7 (strongly agree), including 
"A lot of times, the traditional ways really are the best," "We should respect the traditions of our elders," and "I am often suspicious when people say that they want to break with tradition."

Donations. Two of the donation jars were for anti-gay organizations, the Traditional Values Association (TVA) and Family First (FF). The TVA was described as explicitly opposing gay rights and gay marriage; FF's opposition to gay rights was more indirect—described as protecting family values. Since social desirability concerns might discourage participants from discriminating in an obvious way, we included these two anti-gay beneficiaries to be sure our dependent variable would capture both blatant and subtle forms of discrimination. One jar was for the Human Rights Coalition (HRC), a pro-gay organization. Three jars were for neutral organizations, including the Cancer Awareness Society, the Universal Children's Fund, and the Emergency Relief Association. The neutral organizations were included to disguise the study's purpose. The dependent variable, anti-gay donations, compares anti-gay donations to pro-gay donations. Anti-gay donations were calculated as the weighted mean proportion of anti-gay donations (TVA+FF) and all donations that were not pro-gay (1-HRC). To correct for the imposed limits of proportional data, all proportions were arcsine-transformed prior to analysis.

\section{Results}

Five participants who failed the manipulation check were excluded. Men and women were equally distributed across the three levels of status condition. Descriptive statistics and correlations among the variables are reported in Table 3. Across all conditions, participants donated $74 \%$ of their money to neutral organizations, $12 \%$ to anti-gay groups, and $14 \%$ to progay groups. Figure 1 shows the mean donation ${ }^{4}$ made to neutral, anti-gay, and pro-gay organizations by condition. Comparing the Low to the Gain condition, the status manipulation had the greatest effect on donations made to pro-gay causes $(t(46)=1.72, p=.09, d=.50)$ 
compared to anti-gay $(t(46)=-1.13, p=.27, d=-.32)$ and neutral causes $t(46)=-0.77, p=.45, d$ $=-.22$ ).

Anti-gay donations were regressed on status condition, SDO and traditional values with all possible interaction terms. Continuous predictor variables were mean-centered (Aiken \& West, 1991). Two dummy variables represented the three levels of status condition, Gain $(0=$ Control, $1=$ Gain $)$ and Low $(0=$ Control, $1=$ Low $)$. Two cases were deemed outliers based on a Q-Q plot of anti-gay donations and excluded from regression analyses.

A summary of the regression analysis is presented in Table 4. Anti-gay donations did not significantly differ by status condition. There were main effects of SDO and traditional values, $\beta=.78, p<.001$, and $\beta=.35, p<.05$, respectively; people high in SDO and traditional values donated a higher proportion of money to anti-gay causes than people low in SDO and traditional values. Additionally, status condition interacted with SDO and traditional values (see Figures 2a and $2 \mathrm{~b}$ ). Tests of simple slopes showed that for the Control and Gain status conditions, SDO predicted anti-gay donations, simple slopes $=0.16, p<.001$ and $0.05, p<.05$, respectively. For the Low status condition, anti-gay donations were not related to SDO, simple slope $=0.01, p=.84$.

A different pattern emerged for the interaction of traditional values and status condition. Tests of the simple slopes showed that traditional values positively correlated with anti-gay donations in the Control and Gain status conditions, simple slopes $=0.05, p<.05$ and 0.06 , $p=0.06$, respectively. In the low status condition, this effect became even more pronounced, simple slope $=0.13, p<.001$.

We expected SDO to predict increased discrimination when gay people were perceived to be gaining status. What we found is the parallel but opposite effect: People high in SDO were most sensitive to status information that suggests gay people do not pose a threat to group 
position; their pattern of donations became less discriminatory (with less money donated to antigay causes and more money donated to the pro-gay cause) in the Low status condition. By contrast, people high in endorsement of traditional values responded to the information that gay people are quite low in status by donating even more money to anti-gay causes compared to the Control and Gain status conditions.

\section{Discussion}

SDO and traditional values were both correlated with more donations to anti-gay causes, but people high in SDO and people with high endorsement of traditional values responded to the status manipulation in different ways. We predicted a backlash effect, expecting high-SDO individuals to become even more anti-gay in their pattern of donations in the Gain status condition, when they perceived greater threat to group position. Instead, we found what might be called "the opposite of backlash." High-SDO individuals showed enhanced tolerance in the Low status condition, donating less money to anti-gay causes (and more money to the pro-gay cause) compared to the Control and Gain status conditions. Giving the impression that group position threat is low may reduce the motivation for high-SDO heterosexuals to discriminate against gay people.

Pratto and Shih (2000) found that SDO was unrelated to implicit prejudice until the identity of the high status group was threatened; under threat, SDO was positively associated with implicit prejudice. Jackson and Esses (2000) found that perceived threat reduced support for the empowerment of immigrants among high-SDO but not low-SDO participants. Similarly, we found when perceived threat to group position was low, SDO was not related to anti-gay donations. High status group members may be motivated to defend their dominant group position only when it is threatened. Interestingly, high-SDO participants were just as anti-gay in the 
Control condition as in the Gain status condition (as in the pilot study). High-SDO members of high status groups may chronically perceive threat to their dominant group position, unless information suggests otherwise.

In marked contrast, people with high endorsement of traditional values became even more anti-gay in their pattern of donations when gay people's status was perceived to be low. At the same time, people with low endorsement of traditional values donated less money to anti-gay causes in the Low status condition. We found that people with high endorsement of traditional values donated more money to anti-gay causes in all three conditions; they did not let up in their anti-gay behavior in the Low status condition but became even more anti-gay when gay people were doing poorly. Do people high in traditional values respond to low status information with increased prejudice, as an opportunity to "hit them while they are down?"

One possibility is that people with highly traditional values are especially sensitive to social norms regarding the acceptability of prejudice and discrimination. Discrimination against gay people was portrayed as pervasive and legitimate in the Low status condition, whereas in the Gaining status condition it was portrayed as infrequent and illegitimate. Thus the more permissive social norms may have encouraged more anti-gay behavior in the Low status condition, especially among those who are close norm followers (Crandall, Eshleman, \& O'Brien, 2002). This explanation is consistent with Duckitt's (2006) dual-process model of individual differences in prejudice proneness, which proposes that social conformity is a predisposing personality trait for Right-Wing Authoritarianism — a central part of which is conventionalism or adherence to traditional values.

\section{General Discussion}


People high in SDO are sensitive to status changes among social groups, particularly when a low status group is making gains (Sidanius \& Pratto, 1999). Seeing gay people as moving up in status may represent a threat to the dominant position of heterosexuals; people who believe that social inequality is legitimate (high-SDO) reacted defensively to this threat by donating money to anti-gay causes. But high-SDO heterosexuals showed more tolerance when perceived threat to group position was low, increasing their donations to the pro-gay cause. Thus endorsing social inequality legitimates prejudice, but only when status positions are threatened. As long as heterosexuals' dominant group position is safe, SDO may delegitimate prejudice against gay people and alleviate discrimination.

An alternative interpretation is that SDO is more about being sensitive to need than about defending dominant group position. Perhaps high-SDO individuals donated more money to antigay groups than low-SDO individuals in the Gain status condition because they believed the gay rights group did not need the money; gay people were already doing well. If this were the case, we would also expect high-SDO individuals to donate less money to anti-gay groups (and more money to pro-gay groups) than low-SDO individuals in the Low status condition when gay rights causes were not doing well. The data do not support this explanation, however, because SDO was unrelated to anti-gay donations in the Low status condition.

These results are consistent with the idea that perception of threat is a motivated process. As suggested by the Justification-Suppression model of prejudice (Crandall \& Eshleman, 2003) and the Justified Discrimination Model (Pereira et al., 2010), perceptions of threat may be constructed in order to justify prejudice and discrimination. Anti-gay donations can be justified when gay people are perceived to be gaining rights and influence. Likewise, anti-gay donations seem less justified when gay people are widely discriminated against. When a person interprets 
status gains as a threat to group position, perceiving threat justifies discriminating against the threatening group. The legitimation of social inequality can be thought of as a state or as a process. Our research suggests it is a process that is based on perception of relative status positions. This perception can be used to legitimate discrimination as a way to promote social inequality. 


\section{References}

Aiken, L. S., \& West, S. G. (1991). Multiple regression: Testing and interpreting interactions, London, England: Sage.

Adorno, T. W., Frenkel-Brunswik, E., Levinson, D. J., \& Sanford, R. N. (1950). The authoritarian personality. New York: Harper.

Altemeyer, B. (1981). Right-wing authoritarianism. Winnipeg, Ontario, Canada: University of Manitoba Press.

Blumer, H. (1958). Race prejudice as a sense of group position. The Pacific Sociological Review, $1,3-7$.

Bobo, L. D. (1999). Prejudice as group position: Microfoundations of a sociological approach to racism and race relations. Journal of Social Issues, 55, 445-472.

Branscombe, N. R., Ellemers, N., Spears, R., \& Doosje, B. (1999). The context and content of social identity threat. In N. Ellemers, R. Spears \& B. Doosje (Eds.), Social identity: Context, commitment, content. (pp. 35-58). Oxford, England: Blackwell Science.

Carpenter, C. (2008). New evidence on gay and lesbian household incomes. Contemporary Economic Policy, 22, 78-94.

Crandall, C. S. (1994). Prejudice against fat people: Ideology and self-interest. Journal of Personality and Social Psychology, 66, 882-894.

Crandall, C. S., \& Eshleman, A. (2003). A justification-suppression model of the expression and experience of prejudice. Psychological Bulletin, 129, 414-446.

Crandall, C. S., Eshleman, A., \& O’Brien, L. T. (2002). Social norms and the expression and suppression of prejudice: The struggle for internalization. Journal of Personality and Social Psychology, 82, 359-378.Duckitt, J. (2006). Differential effects of Right Wing 
Authoritarianism and Social Dominance Orientation on Outgroup Attitudes and Their Mediation by Threat From and Competitiveness to Outgroups. Personality and Social Psychology Bulletin, 32, 684-696.

Eibach, R. P., \& Keegan, T. (2006). Free at last? Social dominance, loss aversion, and white and black Americans' differing assessments of racial progress. Journal of Personality and Social Psychology, 90, 453-467.

Esses, V. M., Jackson, L. M., \& Armstrong, T. L. (1998). Intergroup competition and attitudes toward immigrants and immigration: An instrumental model of group conflict. Journal of Social Issues, 54, 699-724.

Fischer, C. (1982). To dwell among friends: Personal networks in town and city. Chicago, IL: University of Chicago Press.

Herek, G. M. (1994). Assessing heterosexuals' attitudes toward lesbians and gay men: A review of empirical research with the ATLG scale. In B. Greene \& G. M. Herek (Eds.), Lesbian and gay psychology: Theory, research, and clinical applications. (Vol. 1, pp. 206-228). Thousand Oaks, CA: Sage Publications.

Jackson, L. M., \& Esses, V. M. (2000). Effects of perceived economic competition on people's willingness to help empower immigrants. Group Processes and Intergroup Relations, 3, 419-435.

Jost, J. T., \& Major, B. (2001). The psychology of legitimacy : Emerging perspectives on ideology, justice, and intergroup relations. New York, NY: Cambridge University Press.

Levin, S. (2004). Perceived group status differences and the effects of gender, ethnicity, and religion on social dominance orientation. Political Psychology, 25, 31-48. 
Pettigrew, T. F., \& Meertens, R. W. (1995). Subtle and blatant prejudice in Western Europe. European Journal of Social Psychology, 25, 57-75.

Pereira, C., Vala, J., \& Costa-Lopes, R. (2010). From prejudice to discrimination: The legitimizing role of perceived threat in discrimination against immigrants. European Journal of Social Psychology, 40, 1231-1250.

Pratto, F., \& Shih, M. (2000). Social dominance orientation and group context in implicit group prejudice. Psychological Science, 11, 515-518.

Pratto, F., Sidanius, J., \& Levin, S. (2006). Social dominance theory and the dynamics of intergroup relations: Taking stock and looking forward. European Review of Social Psychology, 17, 271-320.

Pratto, F., Sidanius, J., Stallworth, L. M., \& Malle, B. F. (1994). Social dominance orientation: A personality variable predicting social and political attitudes. Journal of Personality and Social Psychology, 67, 741-763.

Pratto, F., Stallworth, L. M., \& Conway-Lanz, S. (1998). Social dominance orientation and the ideological legitimization of social policy. Journal of Applied Social Psychology, 28, 1853-1875.

Sidanius, J., \& Pratto, F. (1999). Social dominance: An intergroup theory of social hierarchy and oppression. New York, NY: Cambridge University Press.

Sidanius, J., Pratto, F., Van Laar, C., \& Levin, S. (2004). Social dominance theory: Its agenda and method. Political Psychology, 25, 845-880.

Sokolowski, R. (2004). The threat of same-sex marriage. America Magazine. June 7, 2004, Vol. 190, 12-16. 
Tajfel, H., \& Turner, J. C. (1986). The social identity theory of intergroup relations. In W. G. Austin \& S. Worchel (Eds.), Psychology of intergroup relations (pp. 7-24). Chicago, IL: Nelson-Hall.

Whitley, B. E., Jr. (1999). Right-wing authoritarianism, social dominance orientation, and prejudice. Journal of Personality and Social Psychology, 77, 126-134.

Whitley, B. E., Jr., \& Ægisdottir, S. (2000).The gender belief system, authoritarianism, social dominance orientation, and heterosexuals' attitudes toward lesbians and gay men. Sex Roles, 42, 947-967. 


\section{Footnotes}

1. We use the term "gay" to refer to the entire LGBT community. We chose this term because it is more inclusive and describes a social identity in contrast to the alternative term "homosexual" which describes sexual behavior.

2. The beneficiaries were based on legitimate organizations such as the Human Rights Campaign, but the names were changed slightly.

3. The manipulation of status did not significantly affect SDO or traditional values, $F \mathrm{~s}<1.5$.

4. The unequal number of donation jars for anti-gay and pro-gay beneficiaries may have increased the total amount of money donated to anti-gay causes relative to pro-gay causes, which is why we used the proportion of money donated to anti-gay causes as the dependent variable for our primary analysis. 


\section{Table 1}

Correlations between SDO, Perceived Status of Gay People, and Prejudice

\begin{tabular}{lcccc}
\hline & 1 & 2 & 3 & 4 \\
\hline 1. SDO & -- & & & \\
2. Perceived Status of Gay People & $.29 \dagger$ & -- & & \\
3. ATL & $-.52 * *$ & $-.69 * *$ & -- & \\
4. ATG & $-.60 * * *$ & $-.67 * * *$ & $.82 * * *$ & -- \\
\hline
\end{tabular}

Note $. \mathrm{SDO}=$ Social Dominance Orientation, $\mathrm{ATL}=$ Attitudes Toward Lesbians, $\mathrm{ATG}=$ Attitudes Toward Gay Men. $\dagger p<.07, p<.01, * * * p<.001$. 


\section{Table 2}

\section{Mission Statements for Beneficiaries}

\begin{tabular}{|c|c|}
\hline $\begin{array}{l}\text { Family First } \\
\text { (Anti-gay) }\end{array}$ & $\begin{array}{l}\text { Family First seeks to preserve time-honored family values } \\
\text { and the institution of the family. Family First is dedicated } \\
\text { to informing, inspiring and rallying those who care deeply } \\
\text { about the family to greater involvement in the moral, } \\
\text { cultural and political issues that threaten our nation. }\end{array}$ \\
\hline $\begin{array}{l}\text { Traditional Values Association } \\
\text { (Anti-gay) }\end{array}$ & $\begin{array}{l}\text { The Traditional Values Association is a church lobbying } \\
\text { organization that strongly opposes the normalization of } \\
\text { sodomy as well as cross-dressing and other deviant sexual } \\
\text { behaviors in our culture. The TVA is working to protect } \\
\text { the traditional definition of marriage in our country as the } \\
\text { sacred union of one man and one woman. }\end{array}$ \\
\hline $\begin{array}{l}\text { Human Rights Coalition } \\
\text { (Pro-gay) }\end{array}$ & $\begin{array}{l}\text { The HRC works to secure equal rights for lesbian, gay, } \\
\text { bisexual, and transgender (LGBT) individuals and } \\
\text { families at the federal and state levels by lobbying elected } \\
\text { officials, mobilizing grassroots supporters, educating } \\
\text { Americans, investing strategically to elect fair-minded } \\
\text { officials and partnering with other LGBT organizations. }\end{array}$ \\
\hline $\begin{array}{l}\text { Cancer Awareness Society } \\
\text { (Neutral) }\end{array}$ & $\begin{array}{l}\text { The Cancer Awareness Society is a nationwide, } \\
\text { community-based voluntary health organization that } \\
\text { provides support to cancer patients and serves the } \\
\text { community through research, education, and advocacy. }\end{array}$ \\
\hline $\begin{array}{l}\text { Emergency Relief Association } \\
\quad \text { (Neutral) }\end{array}$ & $\begin{array}{l}\text { The Emergency Relief Association, a national } \\
\text { humanitarian organization led by volunteers, helps people } \\
\text { prevent, prepare for, and respond to emergencies. }\end{array}$ \\
\hline $\begin{array}{l}\text { Universal Children's Fund } \\
\text { (Neutral) }\end{array}$ & $\begin{array}{l}\text { The Universal Children's Fund advocates for children's } \\
\text { rights. Funding is used to expand children's opportunities } \\
\text { worldwide so that they may reach their full potential. }\end{array}$ \\
\hline
\end{tabular}




\section{Table 3}

Descriptive Statistics and Correlations between the Variables

\begin{tabular}{llcc}
\hline & 1 & 2 & 3 \\
\hline 1. Anti-gay donation & -- & & \\
2. SDO & $.35^{* *}$ & -- & \\
3. Traditional Values & $.61^{* * *}$ & .13 & -- \\
Means (standard deviations) & $0.44(0.16)$ & $1.98(0.76)$ & $3.60(1.18)$ \\
\hline
\end{tabular}

Note. Anti-gay donation is the proportion of money donated to anti-gay organizations. 


\section{Table 4}

Regressing Anti-gay Donations on SDO, Traditional Values, and Status Condition

\begin{tabular}{|c|c|c|c|c|c|}
\hline Step & Predictors & $\bar{\beta}$ & $t(55)$ & $R^{2}$ & $\Delta R^{2}$ \\
\hline \multirow[t]{5}{*}{1} & Intercept & & $16.48 * * *$ & .47 & $.47 * * *$ \\
\hline & Gain & .09 & 0.79 & & \\
\hline & Low & -.03 & -0.24 & & \\
\hline & SDO & .78 & $3.84 * * *$ & & \\
\hline & Traditional Values & .35 & $2.28 *$ & & \\
\hline \multirow[t]{5}{*}{2} & SDO x Gain & -.40 & $-2.02 *$ & .58 & $.11 *$ \\
\hline & SDO x Low & -.40 & $-2.48 *$ & & \\
\hline & Traditional Values x Gain & .07 & 0.56 & & \\
\hline & Traditional Values x Low & .32 & $2.73 * *$ & & \\
\hline & SDO x Traditional Values & -.28 & -1.43 & & \\
\hline \multirow[t]{2}{*}{3} & $\begin{array}{l}\text { Gain x SDO x Traditional } \\
\text { Values }\end{array}$ & .18 & 1.08 & .59 & .01 \\
\hline & $\begin{array}{l}\text { Low x SDO x Traditional } \\
\text { Values }\end{array}$ & .14 & 0.87 & & \\
\hline
\end{tabular}

Note. Gain and Low are dummy-coded variables for status condition with reference to the Control condition. $* p<.05, * * p<.01, * * * p<.001$. 


\section{Figure 1}

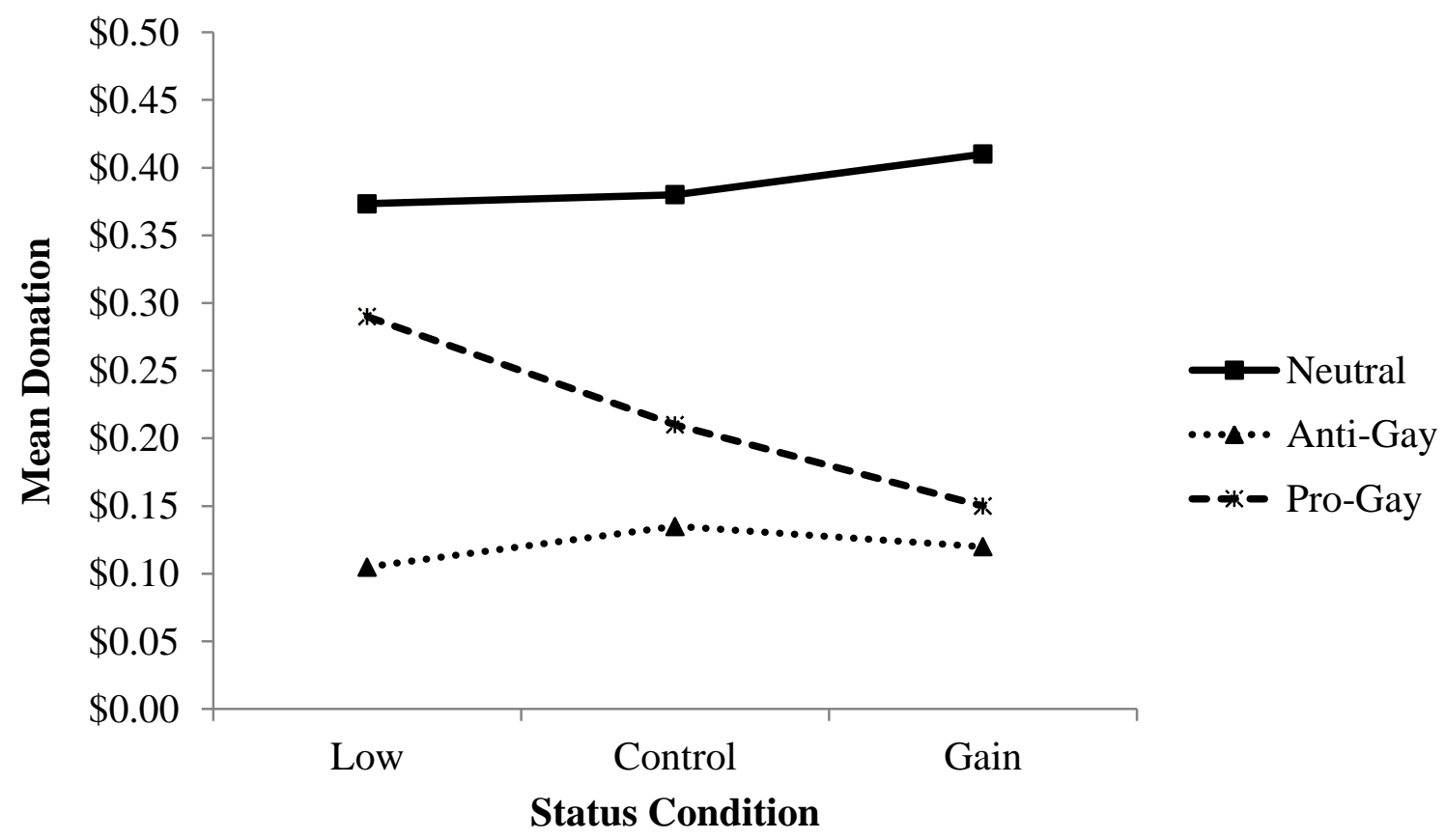


Figures 2a and 2b

Fig. 2a

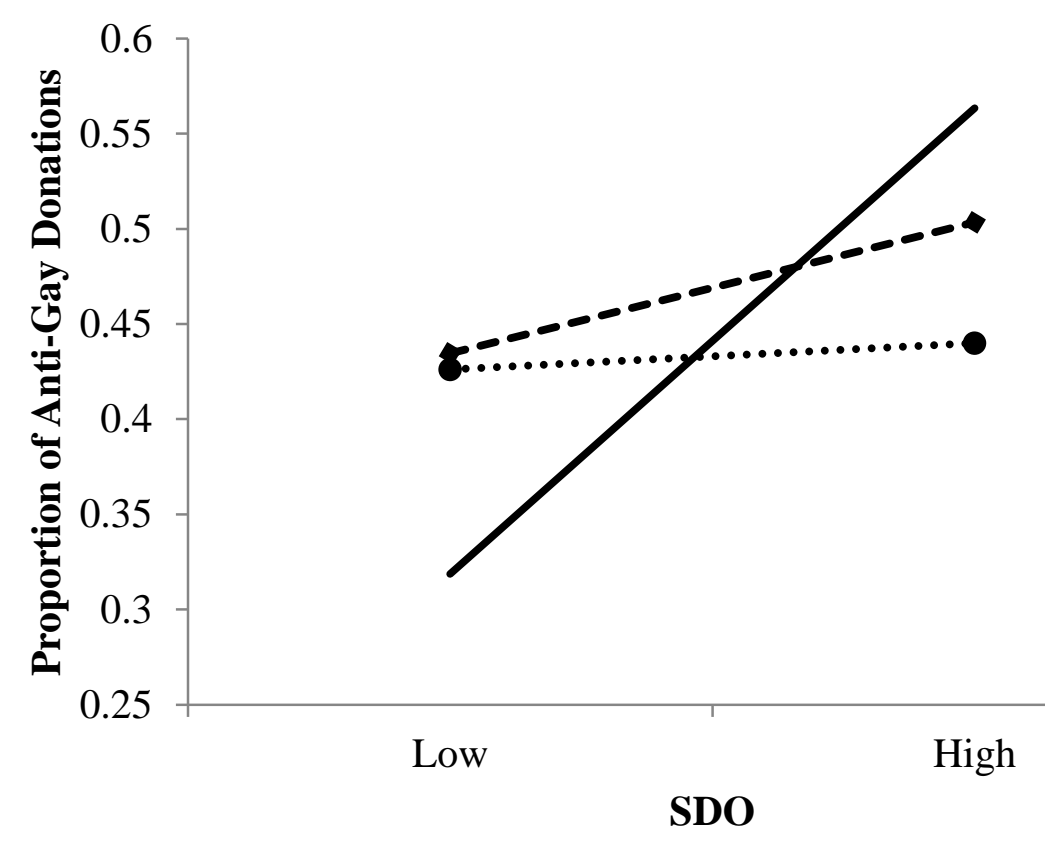

Fig. 2b

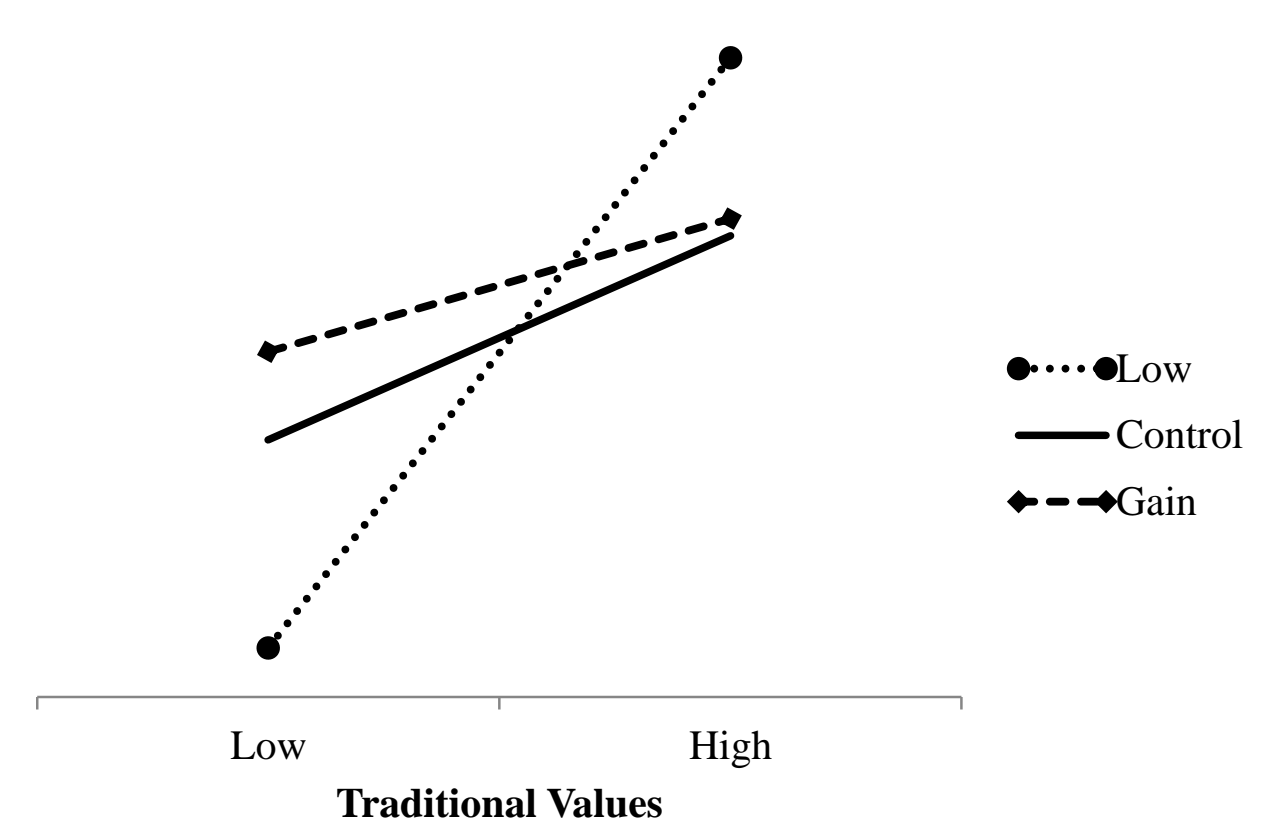




\section{Figure Captions}

Figure 1. Donations to neutral, anti-gay, and pro-gay organizations by status condition

Figures 2a and 2b. SDO (Fig. 2a) and Traditional Values (Fig. 2b) as predictors of anti-gay donations by status condition. The categories "High" and "Low" represent one standard deviation above and below the mean. 